\title{
Gender-Specific Aspects of Lynch Syndrome and Familial Adenomatous Polyposis
}

\author{
Ralph Schneider ${ }^{\mathrm{a}} \quad$ Claudia Schneider ${ }^{\mathrm{b}} \quad$ Christian Jakobeit $^{\mathrm{c}}$ \\ a Department of Visceral, Thoracic and Vascular Surgery, Philipps University Marburg, \\ ${ }^{\mathrm{b}}$ Department of General and Visceral Surgery, \\ ${ }^{c}$ Department of Gastroenterology, HELIOS St. Josefs-Hospital, Bochum-Linden, \\ dDepartment of Surgery, Caritas-Hospital St. Josef, Regensburg, Germany
}

Alois Fürst ${ }^{d} \quad$ Gabriela Möslein $^{b}$

\section{Keywords}

Lynch syndrome - Familial adenomatous polyposis - FAP . Gender-specific aspects · Surgery

\section{Summary}

Background: The most frequent hereditary colorectal cancer (CRC) syndromes are Lynch syndrome and familial adenomatous polyposis (FAP), accounting for approximately $5 \%$ of the CRC burden. Both are characterized by an autosomal dominant mode of transmission and require an individualized approach of intensified screening and prophylactic surgery. Methods: In this review, we provide an overview of the literature regarding gene- and gender-specific aspects of Lynch syndrome and FAP. Based upon available data, a personalized approach when treating patients and families with these predisposition syndromes is increasingly warranted. Results: In Lynch syndrome patients, men have a significantly higher lifetime risk and earlier age of manifestation for CRC - especially in MSH6 mutation carriers. Moreover, incidence of gastric, bladder, and urothelial cancers is much higher in males. Females with an MSH6 mutation have to be aware of a very high risk especially for endometrial, but also for ovarian cancer. In FAP families, females are more prone to papillary thyroid cancers and also to desmoid tumors. Conclusion: It is timely to suggest gene- and gender-based adapted screening and surgical recommendations for Lynch syndrome patients. In FAP patients, females should follow intensified screening recommendations for early detection of precursors or papillary cancer of the thyroid. Moreover, desmoid patients should primarily not be subjected to surgical resection but rather to a gender-specific conservative medical treatment.

\section{Schlïsselwörter}

Lynch-Syndrom · Familiäre adenomatöse Polyposis · FAP . Genderspezifische Aspekte · Chirurgie

\section{Zusammenfassung}

Einleitung: Die häufigsten erblichen kolorektalen Prädispositionssyndrome sind das Lynch-Syndrom und die familiäre adenomatöse Polyposis (FAP), die für ungefähr $5 \%$ der gesamten kolorektalen Karzinome (KRK) verantwortlich sind. Beide Syndrome sind durch einen autosomal-dominanten Vererbungsmodus charakterisiert und erfordern ein individualisiertes Vorgehen in Bezug auf Vorsorge- und Früherkennungsempfehlungen sowie die Indikation zu einer prophylaktischen Chirurgie. Methoden: In dieser Übersichtsarbeit wird ein aktuelles Update über die in der Literatur verfügbaren gen- und genderspezifischen Aspekte des Lynch-Syndroms und der FAP zusammengestellt. Basierend auf diesen Erkenntnissen ist zunehmend ein individualisiertes Vorgehen für Familien und Patienten mit hereditären Veranlagungen zu beachten. Ergebnisse: Beim Lynch-Syndrom haben Männer vor allem solche mit einer MSH6-Mutation - ein signifikant höheres Lebenszeitrisiko und ein jüngeres Erstmanifestationsalter für KRK. Darüber hinaus ist die Inzidenz für Magen-, Blasen- und Urothelkarzinome bei Männern ebenfalls erhöht. Insbesondere bei Frauen mit MSH6-Mutation wird ein deutlich erhöhtes Risiko für Endometrium- und Ovarialkarzinome beobachtet. Bei der FAP sind die papillären Schilddrüsenkarzinome, die fast ausschließlich bei Frauen auftreten, sowie Desmoide, die gehäuft bei jungen Frauen beobachtet werden, genderspezifisch interessant. Schlussfolgerungen: Es ist gerechtfertigt, für Patienten mit Lynch-Syndrom ein gen- und genderspezifisches Vorsorge- und Früherkennungsprogramm und prophylaktische chirurgische Maßnahmen einzufordern. Bei FAP-Patienten sollte eine intensivierte Früherkennung für papilläre Schilddrüsenkarzinome bei Frauen erfolgen und bei Vorliegen einer Desmoiddiagnose eine primär nichtoperative Vorgehensweise mit einer geschlechtsspezifischen medikamentösen Therapie bevorzugt werden.

\section{KARGER \\ Fax +497614520714 \\ Information@Karger.com}

www.karger.com (c) 2014 S. Karger GmbH, Freiburg

$1662-6664 / 14 / 0302-0082 \$ 39.50 / 0$

Accessible online at:

www.karger.com/vim
Prof. Dr. Gabriela Möslein

Abteilung für Allgemeine und Viszeralchirurgie - Koloproktologie HELIOS St. Josefs-Hospital

Axstraße 35, 44879 Bochum, Germany

gabriela.moeslein@helios-kliniken.de 


\section{Introduction}

Colorectal cancers (CRC) are the second most frequent malignancy for both males and females in Germany, affecting $6 \%$ of the population. Of these, $65 \%$ are sporadic, $25 \%$ familial of polygenic origin, and $5-10 \%$ pertain to an autosomal dominant mode of inheritance. In this last group, the most frequent hereditary predisposition is Lynch syndrome, accounting for $3-5 \%$ of all CRC [1].

\section{Hereditary Non-Polyposis Colorectal Cancer/Lynch Syndrome}

Lynch syndrome is defined as the detection of a pathogenic mutation in one of the so-called mismatch repair (MMR) genes after exclusion of a BRAF mutation. Hereditary nonpolyposis colorectal cancer (HNPCC) is defined through the fulfillment of the Amsterdam criteria based on the family cancer pedigree information by taking $\mathrm{CRC}$ and other extracolonic cancers as well as age at diagnosis into account. HNPCC or Lynch syndrome must be suspected if microsatellite instability (MSI) using the PCR-based method is detected, or if a loss of protein expression in one of the MMR genes is identified immunohistochemically either in the biopsy or in the tumor specimen. However, methylation of hMLH1 must be excluded if the loss of protein expression occurred in MLH1. After detection of MSI or MMR loss of protein expression, testing for a germline mutation in one of the MMR genes in a blood sample should be performed, obviously after obtaining 'informed consent'. The detection of a germline mutation in an index patient enables predictive testing for relatives interested in this option and should be embedded in genetic counseling.

On a clinical level, HNPCC/Lynch syndrome leads to a high predisposition for colorectal, gynecological, and other tumors (table 1) with lifetime risks as high as $80-90 \%$, depending on gene and gender.

MMR genes are responsible for the identification and repair of nucleotide mismatches that may occur during DNA replication. Of the known MMR genes (MSH2, MLH1, MSH6, MSH3, PMS1, PMS2), mutations have been reported to occur predominantly in either the MSH2 or MLH1 genes in $90 \%$ of the cases $[2,3]$. This may, however, be caused by selection bias since these genes were the first identified and, as a result, most patients have been subjected to an analysis of these and not usually to all four of the routinely recommended MMR genes today, i.e. hMSH2, hMLH1, hMSH6, and PMS2. The role of a mutation in the EPCAM region, which is located before the MSH gene and which can lead to an inactivation of MSH2, is still unclear [4]. However, even if this is not yet conclusively clarified, an association with Lynch syndrome has to be assumed [5].
Table 1. Cumulative lifetime risks of Lynch syndrome patients [41]

Table 2. Revised Bethesda Guidelines [6]; fulfillment of only one criterion necessary to warrant MSI testing

\begin{tabular}{lcl}
\hline Carcinoma & Lynch syndrome, \% & General population, \% \\
\hline CRC - males & $54-74$ & 5 \\
CRC - females & $30-52$ & 5 \\
Endometrial cancer & $28-60$ & 2 \\
Ovarian cancer & $6-7$ & 1 \\
Gastric cancer & $6-9$ & $<1$ \\
Cancer of the small bowel & $3-4$ & $<1$ \\
Pancreatic cancer & $<1-4$ & 1 \\
Cancer of the hepatobiliary tract & 1 & rare \\
Cancer of the urogenital tract & $3-8$ & rare \\
Brain cancer & $2-3$ & $<1$ \\
Sebaceous skin tumor/keratoacanthoma & $1-9$ & rare \\
\hline
\end{tabular}

1. CRC has been diagnosed before the age of 50 years.

2. Presence of synchronous, metachronous CRC or other Lynch syndrome-associated tumors ${ }^{\mathrm{a}}$, regardless of age.

3. CRC with MSI-H histology ${ }^{\mathrm{b}}$ diagnosed in a patient who is less than 60 years of age.

4. CRC diagnosed in a patient with one or more first-degree relatives with a Lynch syndromeassociated tumor, with one of the cancers being diagnosed before the age of 50 years.

5. CRC diagnosed in a patient with two or more first- or second-degree relatives with Lynch syndrome-associated tumors, regardless of age.

${ }^{a}$ Endometrial, stomach, ovarian, pancreas, hepatobiliary tract, small intestine, brain tumors (usually glioblastoma in Turcot syndrome), sebaceous gland adenomas, and keratoacanthomas in Muir-Torre syndrome, transitional cell carcinoma of renal pelvis or ureter.

bPresence of tumor-infiltrating lymphocytes, Crohn's like lymphocytic reaction, mucinous/signet ring differentiation, or medullary growth pattern. 
Table 3. Amsterdam criteria [42, 43]; families must fulfill all criteria
Amsterdam I criteria

1. CRC has been diagnosed in at least three relatives.

2. One of them should be a first-degree relative of the other two.

3. At least two successive generations are affected.

4. At least one CRC was diagnosed before the age of 50 years.

5. FAP has been excluded.

6. CRC are verified by histopathological examination.

Amsterdam II criteria

1. Lynch syndrome-associated cancer ${ }^{a}$ has been diagnosed in at least three relatives.

2. One of them should be a first-degree relative of the other two.

3. At least two successive generations are affected.

4. At least one cancer was diagnosed before the age of 50 years.

5. FAP has been excluded.

6. Tumors are verified by histopathological examination.

${ }^{\mathrm{a}} \mathrm{CRC}$, cancer of the endometrium, small bowel, ureter, or renal pelvis.
Clinical screening for potential Lynch syndrome patients according to the new German S3 guidelines should still be based on the 'revised Bethesda criteria' (table 2) $[6,7]$ and the Amsterdam I or Amsterdam II criteria (table 3) [8]. Many countries have already established systematic tumor screening at least for CRC, some with an upper age limit of 70 years. The European (Mallorca) guidelines also recommend this approach due to an unacceptably high number of missed cases of up to $50 \%$ when identification is based on the clinical criteria. Therefore, an amendment and update of these newly published German S3 guidelines must already be taken into consideration.

Lynch syndrome was first described by the pathologist Warthin in 1895 [9], who identified the family of his seamstress with a high rate of gynecological cancers in association with CRC. Henry Lynch later followed up on 'Family G', and due to the high detection rate mostly of CRC in later generations he proposed the term 'hereditary non-polyposis colorectal cancer' (HNPCC). After pinpointing deficient MMR genes as the causative underlying molecular pathogenetic mechanism for the syndrome, eventually the underestimated frequency of extracolonic cancers was newly acknowledged. Families without mutation but with fulfillment of the Amsterdam criteria - referred to as HNPCC - differ clinically from Lynch syndrome families, especially due to a higher age of manifestation and an overall lower rate of extracolonic cancers $[10,11]$. After clinical demonstration of this difference the terms HNPCC and Lynch syndrome were defined for differentiation between the two entities.

\section{Gender Differences}

\section{Colorectal Cancer}

The lifetime risk for CRC in patients with Lynch syndrome is $28-75 \%$ for males and therefore higher than in females, with an overall risk of 24-52\% [7]. Especially in the case of
MSH6 mutations a clear genotype-phenotype correlation has been established. Females with a mutation in MSH6 have a cumulative CRC lifetime risk of $30 \%$ whereas men have a risk of $54 \%$.

The overall younger average age at manifestation of Lynch syndrome-associated CRC of 45 years is noteworthy and approximately 20 years lower than in the sporadic counterpart. However, many Lynch syndrome patients are older at the time of their first CRC diagnosis, as observed by Hampel et al. [12] in a study from 2005 in which the median age for the first diagnosis of a CRC in 373 family members with Lynch syndrome was 61.2 years of age. Furthermore, Lynch syndrome patients demonstrate frequent synchronous and metachronous CRC in $18 \%$ and $24-30 \%$ of all cases, respectively, at 10 years and $50 \%$ at 15 years after diagnosis of a CRC [1315]. Although there is a slight right-sided predominance of the CRC, it is important to acknowledge that $20 \%$ of the index patients in Germany are diagnosed with rectal cancer [16].

\section{Gynecological Cancer}

Endometrial cancer and ovarian cancers occur in female Lynch syndrome patients with a lifetime risk of $28-60 \%$ [17] and $6-7 \%$ [18], respectively. The risk for occurrence of endometrial cancer in MSH6 mutation patients may be as high as $36 \%$ until the age of 60 and $71 \%$ until the age of 70 [19]. In contrast to this very high cancer incidence associated with an MSH6 mutation, the risk for these cancers in Lynch syndrome patients with an MLH1 or MSH2 mutation is 'only' $24 \%$ and $37 \%$, respectively, until the age of 70 [20]. Overall, the risk for endometrial cancer is substantially higher than previously recognized, and endometrial cancer should be clinically acknowledged as the second most frequent index or sentinel cancer for Lynch syndrome.

\section{Cancer of the Urinary Tract}

Urothelial cancers including those originating from the ureter and the renal pelvis occur 22 times more frequently 
Table 4. Recommendations for surveillance in Lynch syndrome mutation carriers in the German S3 guideline [23]

\begin{tabular}{|c|c|c|c|c|c|c|c|c|c|}
\hline & \multicolumn{2}{|c|}{ Colonoscopy } & \multicolumn{2}{|c|}{ Gastroscopy } & \multicolumn{2}{|c|}{ Abdominal ultrasound } & \multicolumn{2}{|l|}{ Gynecology } & \multirow[t]{2}{*}{ Other } \\
\hline & $\begin{array}{l}\text { interval, } \\
\text { years }\end{array}$ & $\begin{array}{l}\text { lower age } \\
\text { limit, years }\end{array}$ & $\begin{array}{l}\text { interval, } \\
\text { years }\end{array}$ & $\begin{array}{l}\text { lower age } \\
\text { limit, years }\end{array}$ & $\begin{array}{l}\text { interval, } \\
\text { years }\end{array}$ & $\begin{array}{l}\text { lower age } \\
\text { limit, years }\end{array}$ & $\begin{array}{l}\text { interval, } \\
\text { years }\end{array}$ & $\begin{array}{l}\text { lower age } \\
\text { limit, years }\end{array}$ & \\
\hline S3 guideline & 1 & $25^{\mathrm{a}}$ & 1 & 35 & 1 & 25 & $\begin{array}{l}1, \text { TVU } \\
\text { endometrium } \\
\text { biopsy }\end{array}$ & $\begin{array}{l}25 \\
35\end{array}$ & $\begin{array}{l}\text { genetic } \\
\text { counseling with } \\
18 \text { years }\end{array}$ \\
\hline
\end{tabular}

${ }^{a}$ Or at least 5 years younger than the youngest age at diagnosis in the family.

TVU $=$ Transvaginal ultrasound.

in Lynch syndrome patients than in the normal population [18]. Males have a 1.6-fold higher risk than females whereas males with an $\mathrm{MSH} 2$ mutation have a lifetime risk of $6-28 \%$ while females with an MSH2 mutation have a risk of $6-12 \%$ [18].

\section{Bladder Cancer}

The association of bladder cancer with Lynch syndrome has been controversially discussed until today. In a recent publication, however, $71 \%$ of the observed bladder cancers occurred in patients with an MSH2 mutation, 10\% had an MLH1 mutation, and 19\% an MSH6 mutation. 90\% (!) of the affected patients were men. The cumulative risk until the age of 70 for a Lynch syndrome-associated bladder cancer was $7.5 \%$ for males and $1 \%$ for females [21].

\section{Prostate Cancer}

Patients with Lynch syndrome have a cumulative risk of $30 \%$ until the age of 70 to develop a prostate cancer (population risk $8 \%$ ). The age of manifestation is significantly lower than in the sporadic population with 60.4 versus 66.6 years [22].

\section{Screening Recommendations}

The recommendations following the new German S3 guideline 'Colorectal Cancer' are summarized in table 4.

The authors suggest that it might be timely to propose gene- and gender-adapted screening recommendations for Lynch syndrome patients. The significantly higher lifetime risk and earlier age of manifestation for $\mathrm{CRC}$ in men and the much lower incidence of CRC in females, especially concerning those with an MSH6 mutation, should be discussed with the patients. At least until large cohorts are evaluated looking into these correlations in more detail, individual family history should also be taken into account. Along the same lines, females should always, but especially in the case of an identified MSH6 mutation, be made aware of their very high risk especially for endometrial but also for ovarian cancer. Similarly, due to the lower incidence of gastric, blad- der, and urothelial cancers, females might not need to follow the stringent recommendations since they are very infrequently affected.

A gene-gender-based recommendation predicated on penetrance should be the target of large international studies such as the International Mismatch Repair Consortium (IMRC) or the Mallorca Group in order to stratify screening recommendations. Compliance of at-risk persons or mutation carriers is much lower worldwide than assumed and an educational issue of importance. However, low complication rates due to screening procedures such as colonoscopy may also be reported since they are existent and sometimes underestimated. A risk-adapted screening recommendation could be beneficial in order to increase compliance, and it may be mentioned that an awareness of physicians regarding the identification and management of patients with HNPCC and Lynch syndrome is required.

\section{Surgery of Lynch Syndrome-Associated Cancers}

In the new German S3 guideline for 'Colorectal Cancer' from 2013 it has now (finally) become a recommendation that the option of 'prophylactically extended colon surgery' should be discussed with a patient before surgery [23]. Due to the substantial rate of $23.7 \%$ for metachronous CRC despite yearly screening intervals in a time period of 20 years [24], subtotal colectomy is the preferred type of surgery in the European, Australasian, and US setting [25, 26]. Furthermore, a large unpublished international study (Schneider C, in preparation) as well as two smaller studies demonstrated that there is no statistically significant difference in the quality of life after a segmental oncological resection or extended prophylactic surgery with subtotal colectomy. The complication rate for the standard oncological versus the extended subtotal colectomy for colon cancer is identical. Therefore, it is the authors' opinion that subtotal colectomy for colon cancer should invariably be discussed with the patients as an equally good option, discussing pros and cons with each patient and taking personal considerations into account (age, occupation, sphincter function, etc.). 


\section{Surgery for Gynecological Cancers}

In contrast to screening for $\mathrm{CRC}$ with an at least frequently identifiable precursor lesion, there is no evidence for a benefit of a screening program for gynecological cancers.

Prophylactic hysterectomy and adenectomy have now (finally) been recommended for females after the completion of family planning or at the age of 40 . This surgery, however, is merely prophylactic and as such is recommended as a standalone procedure in the situations described above. Nevertheless, in order to spare patients the sequelae of an additional operation at the time of a CRC, this prophylactic option should be offered as a simultaneous procedure. Although no evidence has been documented, pipelle aspiration biopsy is recommended on a yearly basis for all female Lynch syndrome patients in the German guidelines. In a large study published in 2006, Schmeler et al. [27] found that $33 \%$ of the females that were managed by screening instead of prophylactic hysterectomy and adenectomy developed an endometrial and $5 \%$ an ovarian cancer. The value of actively suggesting the option of prophylactic gynecological surgery to female patients must be underlined and is strongly endorsed by the authors.

\section{Familial Adenomatous Polyposis}

Familial adenomatous polyposis (FAP) is caused by a mutation in the APC gene and follows an autosomal dominant mode of inheritance. It is the most frequent polyposis syndrome of the colorectum. Clinically, FAP is defined by the occurrence of more than 100 adenomas in the colorectum; left untreated, a complete penetrance of CRC is observed, since virtually all patients develop CRC. There is also an increase of duodenal cancers, with a cumulative lifetime risk of approximately $5 \%$ [28]. Beyond other extraintestinal manifestations that are basically not as clinically relevant such as osteomas, epidermoid cysts, and retinal alterations (congenital hypertrophy of the retinal pigment epithelium (CHRPE)), there is a somewhat increased risk of hepatoblastoma in childhood, and later in age papillary thyroid cancers and meduloblastomas also demonstrate an increased frequency. Taking gender into account, papillary thyroid cancers occur almost only in females. Also of note is that desmoid tumors (mesenteric fibromatosis) occur mainly in younger females and are much less frequent in males.

Desmoids, also termed as aggressive fibromatosis, are semi-malignant or semi-benign tumors that grow infiltrative locally, mimicking malignancy, but do not metastasize. Clinically, desmoids are categorized according to their localization into intraabdominal, extraabdominal, and abdominal wall desmoids. The clinical symptoms depend on the localization and may reach, among others, from a painless mass to a complete bowel obstruction, obstruction of the ureter, and intesti- nal perforation. Although sporadic desmoids are extremely rare $(0.03 \%$ of all malignancies $)$, up to $50 \%$ of all FAP patients may develop desmoids [29].

The risk depends both on gender and familial occurrence (2.5-fold increased risk, if a first-degree relative has a desmoid diagnosis) [30]. Most frequently, those families are affected that have a deleterious mutation in the APC gene beyond codon 1444 [31]. Therefore, the disease risk in comparison to the sporadic population is increased by the factor of 800 [32], although desmoids certainly remain underdiagnosed if they do not become symptomatic, or are systematically screened for.

Desmoids are the second most frequent cause of mortality after CRC [33]. In a sporadic population, desmoids occur in a male:female ratio of 1:1.4-1.8. However, when analyzing the desmoids of the abdominal wall the distribution rises to $1: 7$ [34]. For FAP patients, the male:female odds ratio is 1:2.1 [35], while in some studies with small numbers the relationship is $1: 3$ [36].

Therapeutic options for desmoids are (radical) surgical resection with a wide resection margin, radiation (50-60 Gy, as single treatment postoperatively or neoadjuvantly), chemotherapy (antracyclines, vinca alkaloids, methotrexate, dacarbazine, temozolomide), tyrosine kinase inhibitors (imatinib, sorafenib), and also non-cytotoxic medical therapies such as high-dose antiestrogens and non-steroidal anti-inflammatory drugs (NSAIDs).

The further course of desmoid patients subjected to any of the above with exception of the high-dose treatment with antiestrogens and NSAIDs is characterized by high or very high recurrence rates. These are reported to be between $30-80 \%$, and desmoids appear to increase in their aggressive growth pattern after surgical treatment $[37,38]$. This led to the recommendation of the American Society of Colon and Rectal Surgeons and the working group of the American Society of Clinical Oncology/Society of Surgical Oncology to prioritize a conservative treatment in FAP patients with intraabdominal desmoids. Both radio- and chemotherapy are described as ultima ratio in otherwise unsuccessfully treated desmoids.

Some case reports have been published on the successful administration of tyrosine kinase inhibitors. Due to the low toxicity, a therapy with imatinib may be initiated before aggressive chemotherapy is considered; however, treatment results with high-dose antiestrogens in combination with the NSAID sulindac are increasingly encouraging.

After the identification of estrogen receptor antagonists in the 1980s desmoid tumors have been treated with antiestrogens (ex iuvantibus). A study with tamoxifene and toremifene demonstrated an equal size or regression of tumor size in $65 \%$ of the patients treated [39]. Raloxifene showed a response mainly in postmenopausal women and a clearly better profile of side effects, especially regarding ovarian cysts. Taking into account the young age of affected FAP patients, raloxifene should be the recommended agent for female patients [40]. 
For NSAIDs, a response to therapy has been reported for different agents. Larger series of successful treatment have been reported only for sulindac. Several different strategies use combination therapies, including our own preferred regimen of combining high-dose antiestrogens with sulindac. With this standardized regimen of treatment we recently analyzed the long-term results in a series of 130 patients with FAP-associated and sporadic desmoid tumors. A statistically significant benefit of this treatment was demonstrated, especially for those patients who were not subjected to previous desmoid surgery (Quast D et al., submitted).

Based on our own as well as published data we recommend treatment of FAP-associated desmoid patients with $300 \mathrm{mg}$ sulindac daily in combination with gender-specific administration of antiestrogens. High-dose tamoxifene (120 mg/day, tapering dosage) and high-dose raloxifene (240 mg/day, tapering dosage) are recommended in male and in female patients, respectively. While side effects are rarely reported for men, ovarian cysts were frequently observed in females and were of therapeutic relevance. A successful management strategy has been the puncturing of large symptomatic ovarian cysts, although their occurrence has primarily been reduced by using raloxifene.

In summary, for FAP patients, desmoids demonstrate gender-specific growth characteristics and a differing response to medical therapy. However, due to low numbers in the series and the usually retrospective data, evidence-based literature is still lacking for this aspect. Nevertheless, this regimen has found its way into the German S3 guidelines as the therapy of first choice for both sporadic and FAP-associated desmoid tumors.

\section{Disclosure Statement}

No financial disclosures or conflicts of interest.

\section{References}

1 Hampel H, Frankel WL, Martin E, Arnold M, Khanduja K, Kuebler P, Clendenning M, Sotamaa K, Prior T, Westman JA, Panescu J, Fix D, Lockman J, LaJeunesse J, Comeras I, de la Chapelle A: Feasibility of screening for Lynch syndrome among patients with colorectal cancer. J Clin Oncol 2008; 26:5783-5788.

2 Ruschoff J, Roggendorf B, Brasch F, Mathiak M, Aust DE, Plaschke J, Mueller W, Poremba C, Kloor M, Keller G, Muders M, Blasenbreu-Vogt S, Rummele P, Muller A, Buttner R: Molecular pathology in hereditary colorectal cancer. Recommendations of the Collaborative German Study Group on hereditary colorectal cancer funded by the German Cancer Aid (Deutsche Krebshilfe) (article in German). Pathologe 2004;25:178-192.

-3 de la Chapelle A: Microsatellite instability phenotype of tumors: genotyping or immunohistochemistry? The jury is still out. J Clin Oncol 2002;20:897899.

4 Ligtenberg MJ, Kuiper RP, Chan TL, Goossens M, Hebeda KM, Voorendt M, Lee TY, Bodmer D, Hoenselaar E, Hendriks-Cornelissen SJ, Tsui WY, Kong CK, Brunner HG, van Kessel AG, Yuen ST, van Krieken JH, Leung SY, Hoogerbrugge N: Heritable somatic methylation and inactivation of MSH2 in families with Lynch syndrome due to deletion of the 3' exons of TACSTD1. Nat Genet 2009;41:112-117.

5 Guarinos C, Castillejo A, Barbera VM, Perez-Carbonell L, Sanchez-Heras AB, Segura A, GuillenPonce C, Martinez-Canto A, Castillejo MI, Egoavil CM, Jover R, Paya A, Alenda C, Soto JL: EPCAM germ line deletions as causes of Lynch syndrome in Spanish patients. J Mol Diagn 2010;12:765-770.

-6 Umar A, Boland CR, Terdiman JP, et al: Revised Bethesda Guidelines for hereditary nonpolyposis colorectal cancer (Lynch syndrome) and microsatellite instability. J Natl Cancer Inst 2004;96:261-268.

7 Vasen HF, Moslein G, Alonso A, et al: Guidelines for the clinical management of Lynch syndrome (hereditary non-polyposis cancer). J Med Genet 2007;44:353-362.
8 Deutsche Krebshilfe: Familiärer Darmkrebs - Verbundprojekt der Deutschen Krebshilfe - Informationsbroschüre für Ärzte (HNPCC, Familiäre Adenomatöse Polyposis, Peutz-Jeghers-Syndrom, Familiäre Juvenile Polyposis). 2001.

9 Warthin AS: Heredity with reference to carcinoma as shown by the study of the cases examined in the pathological laboratory of the University of Michigan, 1895-1913. Arch Intern Med 1913;117:206-212.

10 Holinski-Feder E, Morak M: Hereditary nonpolyposis colorectal carcinoma: state of the art (article in German). Dtsch Med Wochenschr 2008;133: 1690-1695.

11 Lindor NM, Rabe K, Petersen GM, et al: Lower cancer incidence in Amsterdam-I criteria families without mismatch repair deficiency: familial colorectal cancer type X. JAMA 2005;293:1979-1985.

12 Hampel H, Stephens JA, Pukkala E, Sankila R, Aaltonen LA, Mecklin JP, de la Chapelle A: Cancer risk in hereditary nonpolyposis colorectal cancer syndrome: later age of onset. Gastroenterology 2005;129:415-421.

13 Lynch HT, de la Chapelle A: Genetic susceptibility to non-polyposis colorectal cancer. J Med Genet 1999;36:801-818.

14 Lynch HT, Harris RE, Lynch PM, Guirgis HA, Lynch JF, Bardawil WA: Role of heredity in multiple primary cancer. Cancer 1977;40(suppl):1849-1854.

15 Mecklin JP, Jarvinen HJ: Clinical features of colorectal carcinoma in cancer family syndrome. Dis Colon Rectum 1986;29:160-164.

16 Goecke T, Schulmann K, Engel C, Holinski-Feder E, Pagenstecher C, Schackert HK, Kloor M, Kunstmann E, Vogelsang H, Keller G, Dietmaier W, Mangold E, Friedrichs N, Propping P, Kruger S, Gebert J, Schmiegel W, Rueschoff J, Loeffler M, Moeslein G: Genotype-phenotype comparison of German MLH1 and MSH2 mutation carriers clinically affected with Lynch syndrome: a report by the German HNPCC Consortium. J Clin Oncol 2006; 24:4285-4292.

17 Watson P, Lynch HT: The tumor spectrum in HNPCC. Anticancer Res 1994;14:1635-1639.
18 Watson P, Vasen HF, Mecklin JP, Bernstein I, Aarnio M, Jarvinen HJ, Myrhoj T, Sunde L, Wijnen JT, Lynch HT: The risk of extra-colonic, extraendometrial cancer in the Lynch syndrome. Int J Cancer 2008;123:444-449.

19 Boilesen AE, Bisgaard ML, Bernstein I: Risk of gynecologic cancers in Danish hereditary non-polyposis colorectal cancer families. Acta Obstet Gynecol Scand 2008;87:1129-1135.

20 Lin KM, Shashidharan M, Thorson AG, Ternent CA, Blatchford GJ, Christensen MA, Watson P, Lemon SJ, Franklin B, Karr B, Lynch J, Lynch HT: Cumulative incidence of colorectal and extracolonic cancers in MLH1 and MSH2 mutation carriers of hereditary nonpolyposis colorectal cancer. J Gastrointest Surg 1998;2:67-71.

-21 van der Post RS, Kiemeney LA, Ligtenberg MJ, Witjes JA, Hulsbergen-van de Kaa CA, Bodmer D, Schaap L, Kets CM, van Krieken JH, Hoogerbrugge N: Risk of urothelial bladder cancer in Lynch syndrome is increased, in particular among MSH2 mutation carriers. J Med Genet 2010;47: 464-470.

22 Grindedal EM, Moller P, Eeles R, Stormorken AT, Bowitz-Lothe IM, Landro SM, Clark N, Kvale R, Shanley S, Maehle L: Germ-line mutations in mismatch repair genes associated with prostate cancer. Cancer Epidemiol Biomarkers Prev 2009;18:24602467.

23 Schmiegel W, Pox C, Reinacher-Schick A, et al: S3 guidelines for colorectal carcinoma: results of an evidence-based consensus conference on February 6/7, 2004 and June 8/9, 2007 (for the topics IV, VI and VII). Z Gastroenterol 2010;48:65-136.

24 Engel C, Rahner N, Schulmann K, Holinski-Feder E, Goecke TO, Schackert HK, Kloor M, Steinke V, Vogelsang H, Moslein G, Gorgens H, Dechant S, von Knebel DM, Ruschoff J, Friedrichs N, Buttner R, Loeffler M, Propping P, Schmiegel W: Efficacy of annual colonoscopic surveillance in individuals with hereditary nonpolyposis colorectal cancer. Clin Gastroenterol Hepatol 2010;8:174-182. 
25 Teutsch SM, Bradley LA, Palomaki GE, Haddow JE, Piper M, Calonge N, Dotson WD, Douglas MP, Berg AO: The Evaluation of Genomic Applications in Practice and Prevention (EGAPP) Initiative: methods of the EGAPP Working Group. Genet Med 2009;11:3-14.

26 Burt RW, Barthel JS, Dunn KB, et al: NCCN clinical practice guidelines in oncology. Colorectal cancer screening. J Natl Compr Canc Netw 2010;8:8-61.

27 Schmeler KM, Lynch HT, Chen LM, Munsell MF, Soliman PT, Clark MB, Daniels MS, White KG, Boyd-Rogers SG, Conrad PG, Yang KY, Rubin MM, Sun CC, Slomovitz BM, Gershenson DM, Lu KH: Prophylactic surgery to reduce the risk of gynecologic cancers in the Lynch syndrome. $\mathrm{N}$ Engl J Med 2006;354:261-269.

28 Bulow S, Bjork J, Christensen IJ, Fausa O, Jarvinen H, Moesgaard F, Vasen HF: Duodenal adenomatosis in familial adenomatous polyposis. Gut 2004;53:381-386.

29 Bertario L, Russo A, Sala P, Varesco L, Giarola M, Mondini P, Pierotti M, Spinelli P, Radice P: Multiple approach to the exploration of genotype-phenotype correlations in familial adenomatous polyposis. J Clin Oncol 2003;21:1698-1707.

30 Gurbuz AK, Giardiello FM, Petersen GM, Krush AJ, Offerhaus GJ, Booker SV, Kerr MC, Hamilton SR: Desmoid tumours in familial adenomatous polyposis. Gut 1994;35:377-381.
1 Caspari R, Friedl W, Propping P: Misleading phenotype in kindred with familial adenomatous polyposis. Lancet 1992;339:1064.

32 Lynch HT, Fitzgibbons R Jr: Surgery, desmoid tumors, and familial adenomatous polyposis: case report and literature review. Am J Gastroenterol 1996:91:2598-2601.

33 Arvanitis ML, Jagelman DG, Fazio VW, Lavery IC, McGannon E: Mortality in patients with familial adenomatous polyposis. Dis Colon Rectum 1990;33:639-642.

34 Pack GT, Ehrlich HE: Neoplasms of the anterior abdominal wall with special consideration to desmoid tumours. Int Abstr Surg 1944;79:177-198.

35 Bertario L, Russo A, Sala P, Eboli M, Giarola M, D'amico F, Gismondi V, Varesco L, Pierotti MA, Radice P: Genotype and phenotype factors as determinants of desmoid tumors in patients with familial adenomatous polyposis. Int J Cancer 2001; 95:102-107.

36 Hansmann A, Adolph C, Vogel T, Unger A, Moeslein G: High-dose tamoxifen and sulindac as first-line treatment for desmoid tumors. Cancer 2004;100:612-620.

37 Kadmon M, Moslein G, Buhr HJ, Herfarth C: Desmoid tumors in patients with familial adenomatous polyposis (FAP). Clinical and therapeutic observations from the Heidelberg polyposis register (article in German). Chirurg 1995;66:997-1005.
8 Soravia C, Berk T, McLeod RS, Cohen Z: Desmoid disease in patients with familial adenomatous polyposis. Dis Colon Rectum 2000;43:363-369.

39 Brooks MD, Ebbs SR, Colletta AA, Baum M: Desmoid tumours treated with triphenylethylenes. Eur J Cancer 1992;28A:1014-1018.

40 Runowicz CD, Costantino JP, Wickerham DL, Cecchini RS, Cronin WM, Ford LG, Vogel VG, Wolmark N: Gynecologic conditions in participants in the NSABP breast cancer prevention study of tamoxifen and raloxifene (STAR). Am J Obstet Gynecol 2011;205:535.e1-5.

41 Weissman SM, Bellcross C, Bittner CC, Freivogel ME, Haidle JL, Kaurah P, Leininger A, Palaniappan S, Steenblock K, Vu TM, Daniels MS: Genetic counseling considerations in the evaluation of families for Lynch syndrome - a review. J Genet Couns 2011;20:5-19.

42 Vasen HF, Mecklin JP, Khan PM, Lynch HT: The International Collaborative Group on Hereditary Non-Polyposis Colorectal Cancer (ICG-HNPCC). Dis Colon Rectum 1991;34:424-425.

43 Vasen HF, Watson P, Mecklin JP, Lynch HT: New clinical criteria for hereditary nonpolyposis colorectal cancer (HNPCC, Lynch syndrome) proposed by the International Collaborative group on HNPCC. Gastroenterology 1999;116:1453-1456. 